A N N A L E S

UNIVERSITATIS MARIAE CURIE-SKŁODOWSKA

LUBLIN - POLONIA

VOL. LXV, 1

SECTIO G

2018

Maria Curie-Skłodowska University, Lublin

magdalena.budyn-kulik@poczta.umcs.lublin.pl

MAGDALENA BUDYN-KULIK

\title{
Violence in Criminology - the Nature, Reasons, and Perspectives
}

Przemoc w kryminologii - istota, przyczyny i zmiany

Violence is a social fact. According to general opinion, it is a negative phenomenon, but one may also perceive it as a neutral phenomenon, just a social fact, because violence has some social functions. ${ }^{1}$

The term "violence" is very broad. ${ }^{2}$ It is not easy to define it. Its range is changing, ${ }^{3}$ what is more, the same behaviors in different social contexts can be interpreted as violence or not. ${ }^{4}$ Not each act is a crime, ${ }^{5}$ some of them can be socially, culturally or legally justified or at least accepted. ${ }^{6}$ Usually "violence"

1 L.A. Coser, Some Social Functions of Violence, [in:] M.E. Wolfgang (ed.), Patterns of Violence. The Annals of the American Academy of Political and Social Science, Philadelphia 1966, no. 364, pp. 8-18.

2 M.E. Wolfgang, A Preface to Violence, [in:] M.E. Wolfgang (ed.), op. cit., pp. 2-7. Cf. also M. Budyn-Kulik, Zabójstwo tyrana domowego. Studium prawnokarne i wiktymologiczne, Lublin 2005, p. 44.

3 T. Hanausek, Przemoc jako forma działania przestępnego, Kraków 1966, p. 11.

4 See: F.H. McClintock, Criminological Aspects of Family Violence, [in:] J.P. Martin (ed.), Violence and the Family, New York-Brisbane-Toronto 1978, p. 82; S.K. Steinmetz, The Cycle of Violence, New York 1977, p. 30; U. Neuebauer, U. Steinbrecher, S. Drescher-Aldendorff (Hrsg.), Gewalt gegen Franen: Ursachen und Interventionsmöglichkeit. Gesellschaft für Familienforschung e.u. (GEFAM). Schriftenseite des Bundesminister für Jugend, Familie, Frauen und Gesundheit, Stuttgart-Berlin-Köln-Mainz 1987, vol. 21, p. 10; R.T. Sigler, Domestic Violence in Context: An Assessment of Community Attitudes, Lexington 1989, p. 65; M.D. Pagelow, L.W. Pagelow, Family Violence, New York 1984, pp. 127-138.

5 See e.g.: T. Hanausek, op. cit., pp. 5-7, 128-177.

6 B. Karolczak-Biernacka, Problem agresji w sporcie, [in:] B. Hołyst (red.), Przemoc w życiu codziennym. Warszawa 1997, pp. 77-130; H.J. Schneider, Przemoc w instytucjach, [in:] B. Hołyst 
means a relationship between individuals, groups of people or between an individual and a group. ${ }^{7}$ The main characteristic of this relationship is the use of overwhelming force by one of the parties or the threat of using $i t^{8}$ that a victim perceives as unjust and undeserved. ${ }^{9}$ Violence consists in intentional influencing active or passive (just by someone's presence).$^{10}$ Two elements are important here. First, violence is only about interpersonal relationships. Second, the force used by one part must be overwhelming. ${ }^{11}$ What is also specific for violence - one person's behavior toward another one does not suit the nature of the relationship between them. ${ }^{12}$ In some definitions, the attention is paid not to interpersonal relationships but to the characteristics of a behavior. The basic elements of an act of violence are: anger, intention of doing harm and the behavior itself that causes harm to someone. ${ }^{13} \mathrm{An}$ important factor from this point of view is the aim of behavior, i.e. the wish to do harm to someone. ${ }^{14}$

(red.), op. cit., pp. 131-143; L. Godzeń, Moralna aprobata zachowań agresywnych a doświadczenia jednostki w zakresie agresji, [in:] B. Urban (red.), Spoleczne konteksty zaburzeń w zachowaniu, Zeszyty Naukowe Uniwersytetu Jagiellońskiego, Prace Pedagogiczne 2001, nr 28, pp. 41-43; F.H. McClintock, op. cit., p. 83; S.K. Steinmetz, The Cycle ..., op. cit., p. 31, 32-35; M.R. Chatterton, The Social Context of Violence, [in:] M. Borland (ed.), Violence in the Family, Manchester 1976, p. 26 ff; L.E. Walker, Psychological Causes of Family Violence, [in:] M. Lystad (ed.), Violence in the Home. Interdisciplinary Perspectives, New York 1986, pp. 74-75; M.D. Pagelow, L.W. Pagelow, op. cit., p. 343 ff; J. Renvoize, Web Violence. A Study of Family Violence, London 1978, p. 31; L.E. Walker, The Battered Woman Syndrome, [in:] R.J. Gelles, D.R. Loseke (eds.), Current Controversies on Family Violence, Newbury Park-London-New Delhi 1993, p. 37; S.K. Steinmetz, The Cycle..., op. cit., pp. 28-40; K. Senthilathiban, R. Madhava Soma Sundaram, S. Karunanidhi, Reactions to Wife Beating: An Opinion Survey Among Students, "Indian Journal of Criminology” 1991, vol. 19, no. 1, pp. 21-29; E. Aronson, Człowiek istota spoteczna, Warszawa 1995, pp. 309-320; R.G. Zimbardo, F.L. Ruch, Psychologia i życie, Warszawa 1994, pp. 609-614; K. Kmiecik-Baran, Młodzież i prawo. Mechanizmy socjologiczno-psychologiczne, Warszawa 2000, p. 20; S.K. Steinmetz, The Cycle..., op. cit., pp. 31-35.

${ }_{7}$ J. Rodniański, Klasyfikacja, źródła i ocena przemocy w stosunkach międzyludzkich, [in:]

B. Hołyst (red.), op. cit., p. 5; M. Budyn-Kulik, Zabójstwo..., op. cit., p. 45.

8 J. Rodniański, op. cit., p. 5; see also: J. Błachut, A. Gaberle, K. Krajewski, Kryminologia, Gdańsk 1999, p. 260; R.T. Sigler, op. cit., p. 65.

9 A.R.K. Mitchell, Violence in the Family, Hove-East Sussex 1978, pp. 11-12; E. Neuebauer, U. Steinbrecher, S. Drescher-Aldendorff, op. cit., p. 9; R.T. Sigler, op. cit., p. 65.

${ }^{10} \mathrm{~W}$. Domachowski, Czy przemoc i agresja sa ze soba powiazane $i$ czy wptywaja na zdrowie psychiczne?, [in:] M. Binczycka-Anholcer (red.), Agresja i przemoc a zdrowie psychiczne, Warszawa-Poznań 2001, p. 19.

11 J. Rodniański, op. cit., p. 6; J. Błachut, A. Gaberle, K. Krajewski, op. cit., pp. 260-261. See also: M. Budyn-Kulik, Zabójstwo ..., op. cit., p. 45.

${ }_{12}$ P. Stratton, Understanding and Treating Child Abuse in the Family Context: An Overview, [in:] K. Browne, H. Hanks, P. Stratton, C. Hamilton (eds.), Early Prediction and Prevention of Child Abuse, Chichester 1988, pp. 193-202.

${ }_{13}$ K. Browne, M. Herbert, Zapobieganie przemocy w rodzinie, Warszawa 1999, pp. 15-16.

${ }^{14}$ M.A. Straus, Conceptualization and Measurement of Battering: Implications for Public Policy, [in:] M. Steinmann (ed.), Woman Battering: Policy Responses, Lincoln 1991, p. 23. 
Violence is not the same as aggression, although they are connected. On the ground of criminal law one can identify violence and aggression. There are a lot of definitions of aggression. ${ }^{15}$ It can be perceived as one of the personality dimensions ${ }^{16}$ or as an unprovoked impulse of looking for self-confirmation by a confrontation with someone. ${ }^{17}$ It is a universal phenomenon which has a complex etiology. ${ }^{18}$

There are many classifications of aggression. According to the sources of motivations, one may point out: primary aggression (it appears as an effect of anger centers stimulation); secondary aggression (which occurs because of other emotions - fear, pain, threat) ${ }^{19}$ According to its source, aggression can be divided into emotional and instrumental. The first is caused by frustration, when an individual is under the influence of unpleasant stimuli. ${ }^{20}$ The second is formed because it allows an individual to fulfill some needs, avoid unpleasant emotions or get satisfaction. A special kind of instrumental aggression is taskaggression. It appears as an individual's reaction toward a social environment's demands. ${ }^{21}$

It is also not easy to settle a relationship between the range of the term "aggressive behavior" and "crime". The attitude that each crime is in fact an act of aggression is not good. There are crimes without direct victims and there are aggressive behaviors that are not crimes. ${ }^{22}$ There is no definition of violence in the Polish Criminal Code. But analyzing the context in which this term is put on it, one can realize that its meaning is narrow. Violence means using physical force (of different level), for instrumental purposes. In the Criminal Code there are several types of crimes that rely on using violence. They are gathered mostly in the chapter: "Crimes Against Life and Health", but they are also placed in other

${ }^{15}$ M. Budyn-Kulik, Zabójstwo..., op. cit., pp. 46-47.

16 J. Błachut, A. Gaberle, K. Krajewski, op. cit., pp. 263-265.

17 A. Frączek, Agresja - psychologiczny punkt widzenia, [in:] A. Frączek (red.), Z zagadnień psychologii agresji, Warszawa 1980, p. 15.

18 E. Fonberg, Fizjologiczna regulacja agresji, „Psychologia Wychowawcza” 1973, nr 3, pp. 276-277; A. Frączek, Agresja..., op. cit., p. 15; A. Wolska, Mechanizmy agresji zabójców, „Czasopismo Psychologiczne” 1997, t. 3, nr 3, p. 196; E. Fonberg, op. cit., p. 277.

19 E. Fonberg, op. cit., pp. 276-277.

${ }^{20}$ Sometimes it is identified with stress. See: J. Reykowski, Funkcjonowanie osobowości $w$ warunkach stresu psychologicznego, Warszawa 1966, p. 220; Z. Skorny, Formy i źródla agresji u dzieci i młodzieży, „Psychologia Wychowawcza” 1973, nr 3, p. 318. Aggression is one of reactions under stress. A. Peyrefitte, Społeczeństwo wobec przemocy. Raport Komitetu Badań nad przemoca, zbrodnia i wystepkiem, Warszawa 1982, p. 107.

${ }^{21}$ A. Frączek, Agresja ..., op. cit., p. 15; A. Wolska, op. cit., p. 196; E. Fonberg, op. cit., p. 277.

22 J.K. Gierowski, Niektóre biopsychiczne determinanty agresywnego zachowania przestępczego, „Studia Kryminologiczne, Kryminalistyczne i Penitencjarne” 1979, t. 9, pp. 153-154; A. Krukowski, Agresja w aspekcie prawa karnego i kryminologii, „Psychologia Wychowawcza” 1973, nr 3, p. 347. 
chapters like e.g. "Crimes Against Property" (robbery and others). ${ }^{23}$ One can divide such types of crime into four groups. The first group involves the crimes that have expressis verbis among their traits "violence": e.g. Art. $119 \S 1,127 \S 1$, $128 \S 1,153 \S 1,191 \S 1,197 \S 1,203,224 \S 1$ and 2, 232, 245, 246, 250, 260, 264 $\S 2,280 \S 1,281,282,289 \S 2,346$. The second group includes the articles with "active attack": Art. $135 \S 1,136,223,345$. In the third group, there are articles that have "to maltreat physically" among the traits: Art. 207, 246, 247, 352. The fourth group consists of the types of crimes that do not have among their traits any of the above terms, but they can be (and usually are) committed with violence, e.g.: Art. 148, 149, 150, 156, 157, 158, 159.

Judiciary and criminal law theoreticians have not formed any good definition of violence. ${ }^{24}$ On the basis of different opinions, one can come to the conclusion that violence is (in its broad meaning) a physical act that is directed against a victim or against the victim's environment. When it is against a victim, it is called violence against a person. By his/her physical act a perpetrator forces a victim to submit his/ her will and to behave in the way he/ she expects. Sometimes violence is directed against the victim's personal (family members) or physical (victim's belongings or animals) environment. ${ }^{25}$ This direct physical influence is usually vis compulsiva. ${ }^{26}$ It may consist in a violation of someone's bodily immunity (battery) that is not a serious use of force yet (i.e. it has not reached the level of "violent assault of a person" - gwalt na osobie) or does not cause the state of victim's helplessness. ${ }^{27}$ The immanent part of violence is the breaking of the victim's resistance, ${ }^{28}$ but it does not necessarily have to involve the threat to the victim's health or life. ${ }^{29}$

${ }_{23}$ J. Błachut, A. Gaberle, K. Krajewski, op. cit., p. 266; M.D. Pełka-Sługocka, L. Sługocki, Przestępstwa przy użyciu przemocy popetniane przez kobiety w Polsce, „Studia Kryminologiczne, Kryminalistyczne i Penitencjarne" 1983, t. 13, pp. 99-101.

${ }_{24}$ M.D. Pełka-Sługocka, L. Sługocki, op. cit., pp. 97-101; W. Kubala, Znamie ,przemocy” w ujęciu art. 123 k.k., „Problemy Praworządności” 1987, nr 8-9, pp. 15-16.

${ }_{25}$ K. Krajewski, O pojęciu przemocy w kryminologii, ,Studia Kryminologiczne, Kryminalistyczne i Penitencjarne" 1988, t. 19, p. 78; M. Budyn-Kulik, M. Kulik, Glosa do uchwaty Sąu Najwyższego $z$ dnia 30 czerwca 2008 r., I KZP 10/08, System informacji prawnej LEX/el. 2009, nr 93962 oraz Glosa do uchwały Sadu Najwyższego z dnia 21 marca 2007 r., I KZP 39/06, PS 2009, nr 5, pp. 134-137; K. Daszkiewicz, Groźba w polskim prawie karnym, Warszawa 1958, pp. 84-91; J. Warylewski, Molestowanie seksualne w miejscu pracy, „Państwo i Prawo” 1999, z. 3, p. 60; postanowienie SN z dnia 16 stycznia 1976 r., VI KZP 36/75, OSNPG 1976, z. 3, poz. 21; wyrok SN z dnia 12 sierpnia 1974 r., Rw 403/74, OSNKW 1974 r., z. 11, poz. 216; uchwała SN z dnia 11 lutego 1971 r., VI KZP 75/70, OSNKW 1971, z. 5, poz. 68; wyrok SA w Krakowie z dnia 26 marca 1984 r., I KR 52/84, KZS 1991, z. 1, poz. 13.

26 A. Zoll, Glosa do uchwaty SN z dnia 10 grudnia 1998 r., I KZP 22/98, OSP 1999, z. 5, poz. 93.

27 Wyrok SN z dnia 20 grudnia 1985 r., Rw 1151/85, OSNPG 1986, z. 5, poz. 111; wyrok SA w Krakowie z dnia 26 marca 1984 r., I KR 52/84, KZS 1991, z. 1, poz. 11.

28 Wyrok SA w Krakowie z dnia 13 listopada 1997 r., II AKa 210/97, KZS 1997, z. 11-12, poz. 48; Wyrok SN z dnia 9 kwietnia 1974 r., IV KR 33/71, OSNPG 71, z. 7, poz. 125.

29 Wyrok SA w Poznaniu z dnia 16 czerwca 1992 r., II AKr 168/92, OSA 1993, z. 4, poz. 16. 
The nature of violence and aggression is a controversial problem: are they intuitive or learned? Probably one's tendency to use violence and aggression is caused by many factors. ${ }^{30}$ Most authors accept the heterogenic concept, although they do not reject completely the thesis of some endogenic (inborn) tendencies to act in a certain way. The mainstream view seems to be the one of an important role of the learning process without denying the inborn factor. ${ }^{31}$ Both the situational factors $^{32}$ and specific characteristics of an individual have an influence on his/her aggressive behavior. ${ }^{33}$

There are lot of theories that try to explain the nature of violence. Using violence is determined by psychological, biological and socio-cultural factors. ${ }^{34}$ But there are also opinions that these factors are responsible only for aggression and that violence is used as a tool to express it; is an instrument associated with force. $^{35}$

Among the theories of violence origins, there are e.g.: the intra-individual theories, biological (genetic, endocrine, neurotransmitter ones, a brain dysfunction theory) theories, the social learning theory, the frustration-aggression theory and the psycho-pathological theory (depressive personality theory and dysfunctional personality theory).$^{36}$ Some authors perceive a society's malfunction as an explanation for violence. ${ }^{37}$ It can be interpreted as an effect of a pathological process in the bonding among people, ${ }^{38}$ as a kind of abnormal functioning of an indi-

30 A. Peyrefitte, op. cit., pp. 99-104; Z. Skorny, op. cit., pp. 316-317; J. Reykowski, Osobowościowe i sytuacyjne przestanki agresji, „Psychologia Wychowawcza” 1973, nr 3, pp. 299 307; J. Nelken, Endogenne czynniki przestępczości w świetle polskiej myśli kryminologicznej, „Państwo i Prawo” 1984, z. 9, p. 87.

${ }^{31}$ E. Aronson, op. cit., p. 307; P.G. Zimbardo, F.L. Ruch, op. cit., pp. 585-592.

32 I. Pospiszyl, Przemoc w rodzinie, Warszawa 1998, pp. 127-132; K.M. Farrington, Stress and Family Violence, [in:] M.A. Straus, T. Hotaling (eds.), The Social Causes of Husband-Wife Violence, Minneapolis 1980, pp. 94-114.

33 J.K. Gierowski, Niektóre..., p. 16; J.K. Gierowski, Wpływ typu i poziomu agresywności sprawcy na zachowania homicidalne, „Psychiatria Polska” 1995, t. XXIX, nr 1, p. 37; S. Geller, Funkcje mechanizmów poznawczych w regulacji agresji, [in:] A. Frączek (red.), Z zagadnień psychologii agresji, Warszawa 1980, p. 94.

34 A. Frączek, O Ericha Fromma koncepcji ludzkiej destruktywności, [in:] A. Frączek (red.), Studia nad uwarunkowaniami i regulacja agresji interpersonalnej, Wrocław 1986, pp. 167-200; D. Szabo, Agresja, przemoc i systemy socjokulturowe: Typologia, „Studia Kryminologiczne, Kryminalistyczne i Penitencjarne" 1975, t. 2, p. 163.

35 J. Heitzman, Stres w etiologii przestępstw agresywnych, Kraków 2002, pp. 45-61; D. Szabo, op. cit., pp. 54-62.

36 A.F. Greene, T.F. Lynch, B. Decker, C.J. Coles, A Psychobiological Theoretical Characterization of Interpersonal Violence Offenders, "Aggression and Violent Behavior" 1997, vol. 2, no. 3, pp. 273-284.

37 A. Peyrefitte, op. cit., p. 93.

38 A. Sankała, Przemoc jako przejaw patologizacji więzi międzyludzkich, [in:] B. Hołyst (red.), op. cit., pp. 55-70. 
vidual or a group that is expressed in the lack of compliance with legal or social rules. Violence is sometimes interpreted as an antonym of love. ${ }^{39}$ Violence may also be described in terms of control. ${ }^{40}$ It is impossible to point out only one separate source of violence; there are a lot of them. ${ }^{41}$

In this paper I am going to focus on the socially-based theories, but first let me present a short brief of biological ones. The basic concept in biological theories is that there is an "aggressive instinct" in each individual. ${ }^{42}$ Aggressive or violent behavior is probably associated with hormones - especially the testosterone level. ${ }^{43}$ A variation of biological theories are evolution-ecology theories that express an adaptive role of aggression. ${ }^{44}$ The connection between aggression and genetics has not been confirmed yet. ${ }^{45}$

Endocrine theories are based on an observation that males of many species are usually more aggressive than females. ${ }^{46}$ This is usually explained by the chromosome $\mathrm{Y},{ }^{47}$ testosterone level ${ }^{48}$ or hypoglycemia, but the research results are unambiguous. ${ }^{49}$ Endocrinal factors have an indirect influence on using violence, among others, through their role in the adaptation to the stress-causing environment. ${ }^{50}$

Neurotransmitter theory associates aggressive behavior with the level of some neurotransmitters: serotonin, norepinephrine, dopamine, monoamine oxidase (MAO). Despite the obvious bond between an impulsive behavior and dysfunctions of the serotonergic system, the connection has not been confirmed yet. Research on the influence of neurotransmitters on aggressive behavior and violence is difficult (because of some ethical and methodological problems). ${ }^{51}$

39 A. Szyszko-Bohusz, Przemoc jako antynomia miłości, [in:] B. Hołyst (red.), op. cit., pp. 51-54; A. Szyszko-Bohusz, Agresja, przemoc i zdrowie psychiczne w relacji do Hipotezy Nieśmiertelności Genetycznej, [in:] M. Binczycka-Anholcer (red.), op. cit., pp. 27-29.

40 J.E. Stets, Domestic Violence and Control, New York 1988, pp. 69-77.

${ }^{41}$ K. Pospiszyl, Narcystyczne źródta agresji interpersonalnej, [in:] B. Hołyst (red.), op. cit., pp. 71-76.

42 A. Moir, D. Jessel, Zbrodnia rodzi się w mózgu. Zagadka biologicznych uwarunkowań przestępczości, Warszawa 1998, p. 45.

${ }_{43}$ D. Szabo, op. cit., pp. 54-55; A. Drząszcz, Oddziaływanie hormonów na agresywna postawę $l u d z i$, ,Studia Kryminologiczne, Kryminalistyczne i Penitencjarne” 1976, t. 5, pp. 157-165; A.R.K. Mitchell, op. cit., pp. 18-19.

44 A. Frączek, Agresja ..., op. cit., p. 9.

45 M.B. Harris, Aggression, Gender and Ethnicity, "Aggression and Violent Behavior" 1996, vol. 1, no. 2, pp. 141-146; D. Szabo, op. cit., p. 56.

${ }^{46}$ A. Moir, D. Jessel, op. cit., s. 16.; M.B. Harris, op. cit., pp. 141-146.

47 A.F. Greene, T.F. Lynch, B. Decker, C.J. Coles, op. cit., pp. 274-275.

48 A.F. Greene, T.F. Lynch, B. Decker, C.J. Coles, op. cit., p. 275; A. Frączek, Agresja ..., op. cit., pp. 12-13; A. Moir, D. Jessel, op. cit., p. 16; A.F. Greene, T.F. Lynch, B. Decker, C.J. Coles, op. cit., p. 275.

${ }^{49}$ See: A. Moir, D. Jessel, op. cit., pp. 37-47; A.F. Greene, T.F. Lynch, B. Decker, op. cit., pp. 274-276.

50 A.F. Greene, T.F. Lynch, B. Decker, C.J. Coles, op. cit., p. 276.

51 Ibidem. 
There are also theories that point out the connection between head injuries (brain dysfunctions) and a tendency to use violence or aggressive behavior. ${ }^{52}$ According to neuropsychology, there are specific regions in the brain that are responsible for irritability and aggression. ${ }^{53}$ There is an association between a dysfunction of frontal brain lobes and common use of violence. ${ }^{54}$ Although after frontal brain lobes injury a person loses the ability to save emotional equilibrium and to control his/her behavior, ${ }^{55}$ probably the frontal brain lobes dysfunction is rather a moderator than the reason for aggressive behavior. ${ }^{56}$

Some authors try to explain the tendency to use violence with mental disease. ${ }^{57}$ This explanation is especially popular among American psychiatrists, but it is not convincing. ${ }^{58}$

Acceptance of biological theories would have to lead to the conclusion that a person could not be responsible for his/her behavior, because it is biologically determined. At present, biological theories are used only as a part of violent nature explanation. Biological factors create a good ground for aggressive behavior but a person is able to control such tendencies and may perform without violence, provided he/she can resist these tendencies and is not affected by additional external factors, e.g. social ones.

That is why the latter seem to be extremely important. As far as the socialeconomic theories are concerned, using violence is associated with the system and a given state's policy. ${ }^{59}$ From the social learning theory perspective, violence (aggression) is one of the social behavior forms ${ }^{60}$ learned by direct experience and observation. ${ }^{61}$ According to this theory, aggression is the effect of biologi-

52 A.F. Greene, T.F. Lynch, B. Decker, C.J. Coles, op. cit., p. 276; A. Frączek, op. cit., p. 12.

53 A.F. Greene, T.F. Lynch, B. Decker, C.J. Coles, op. cit., p. 276; C.J. Golden, M.L. Jackson, A. Peterson-Rohne, S.T. Gontkovsky, Neuropsychological Correlates of Violence and Aggression: A Review of the Clinical Literature, "Aggression and Violent Behavior" 1996, vol. 1, no. 1, pp. 3-25.

${ }_{54}$ C.J. Golden, M.L. Jackson, A. Peterson-Rohne, S.T. Gontkovsky, op. cit., pp. 9-10.

55 A.F. Greene, T.F. Lynch, B. Decker, C.J. Coles, op. cit., p. 278; C.J. Golden, M.L. Jackson, A. Peterson-Rohne, S.T. Gontkovsky, op. cit., p. 3.

56 A.F. Greene, T.F. Lynch, B. Decker, C.J. Coles, op. cit., p. 278.

${ }^{57}$ D. Martin, Battered Wives (revised, updated), San Francisco 1981, p. 74; G. Hague, E. Malos, Domestic Violence. Action for Change, Cheltenham 1994, pp. 54-55; M.R. Chatterton, op. cit., p. 30; I. Karlsson, Ein Gebrochenes Tabu. Frauenhäuser in Österreich, Wien 1988, p. 10; J. Renvoize, op. cit., p. 30, 33; Violence Against Women in the Family-United Nations Office at Vienna, Centre for Social Development and Humanitarian Affairs, New York 1989, p. 28.

58 See: J. Renvoize, op. cit., pp. 30-31.

${ }^{59}$ D. Szabo, op. cit, pp. 55-56.

${ }^{60}$ A.F. Greene, T.F. Lynch, B. Decker, C.J. Coles, op. cit., p. 278; S.M. Andersen, T.B. Boulette, A.H. Schwartz, Psychological Maltreatment of Spouses, [in:] R.T. Ammerman, M. Hersen (eds.), Case Studies in Family Violence, New York-London 1991, pp. 307-308; A. Frączek, op. cit., p. 11. Critical remarks see: J.K. Gierowski, Wplyw..., op. cit., p. 34.

${ }^{61}$ A.F. Greene, T.F. Lynch, B. Decker, C.J. Coles, op. cit, p. 278. 
cal factors (instinctive routs) and learning (arousal of aggression) ${ }^{62} \mathrm{~A}$ person experiences benefits (awards) or losses (punishments) as a consequence of using violence. By observing others a person learns about possible behaviors and their consequences. ${ }^{63}$ In a process called "vicarious expectancy learning" a person may realize (while observing someone's violent behaviour) if and what kind of punishment or award he/she may expect for his/her violent behaviour. ${ }^{64}$

There are a lot of psychological aggression (violence) theories. One of them is an exploration (cognition) concept ${ }^{65}$ In this model the crucial thing is the process of knowing the world. A child looks for an unstable balance between getting the sense of being safely dependent (on parents or caregivers) and an aggressive tendency to move beyond these limitations and perceive cognition. Cognition is connected with making a distance between a child and his/her parents. Their presence gives the sense of security and stability, so going away is associated with fear. When parents force a child to learn the world faster than he/she is ready, frustration may appear. It may cause an aggressive behavior: a child may attack parents, parents may attack a child. ${ }^{66}$ Nowadays, except the natural acceleration of development caused, among others, by using technically advanced devices, also the "forced" acceleration can be observed. Parents are starting to stimulate their child at a very early stage of his/her development. Because of that they are not spending too much time together and the deep relationship between them has little chance to develop. A child is being treated as an object, which makes it easier for parents to use violence against him/her. This way a child learns how to treat people and how to use violence.

The most important social factor seems to be a formal perception of violence - does the society (on a formal declarative level) accept it as a method of communication or not? In the previous years, there have been a lot of formal attempts to exclude violence from the public sphere. Many different methods have been used: social campaigns against violence, legal changes (e.g. the ban on physical children reprimand was introduced into the Family and Custody Code, the acts of violence in family are being counteracted; there are now numerous penal measures against family violence wrong-doers in the Criminal Code as well as the procedural measures like conditional police custody in the Criminal Procedure Code).

${ }^{62}$ S.K. Steinmetz, Wife-beating, Husband-beating - A Comparison of the Use of Physical Violence Between Spouses to Resolve Marital Fights, [in:] M. Roy (ed.), Battered Woman: A Psychosociological Study of Domestic Violence, New York 1977, p. 64.

${ }_{63}$ A.F. Greene, T.F. Lynch, B. Decker, C.J. Coles, op. cit., p. 278; D.G. Dutton, Limitations of Social Learning Models in Explaining Intimate Aggression, [in:] X.B. Arriaga, S. Oskamp (eds.), Violence in Intimate Relationships, Thousand Oaks-London-New Delhi 1999, pp. 73-90.

${ }^{64}$ A.F. Greene, T.F. Lynch, B. Decker, C.J. Coles, op. cit., p. 278.

${ }_{65}$ A.R.K. Mitchell, op. cit., p. 16.

${ }^{66}$ Ibidem, pp. 16-17. 
Nonetheless, violence and aggressive behavior have not always been socially condemned. They have very often been accepted - either implicitly or explicitly. Social acceptance of violence expresses itself in its presence in literature and art, even in fairy tales, songs, and poems for children. ${ }^{67}$ One of the socially accepted forms of violence is sport (wrestling, boxing). ${ }^{68}$ Many people declare condemnation of violence while it is an abstraction, because in their lives they use it themselves. ${ }^{69}$ This attitude is very often formed by a very important social factor, i.e. the media - television and the Internet. Violence is present in almost every movie, series, commercial, contest. ${ }^{70}$ Easy and anonymous access to the Internet lets people show their worst instincts - by downloading materials full of violence or by commenting others in a very aggressive way ("hate"). One can kill and harm people in electronic games and is rewarded for this (with scores, fame in social media). Media are the main source of information about the surrounding world. They influence the socialization and education processes. The research results are unequivocal. On the one hand, there is evidence that media in many ways promote the use of violence in a society: by modeling, victimization, fear exaggeration, reality perception disturbing or desensitization. On the other hand, there is research that excludes any media influence on using violence. ${ }^{71}$ This discrepancy is easy to explain, because both the kind of influence (positive-negative) and its degree depends on the presence and interaction of other factors like: the age of the person affected, giving balance by conscious parental reactions, previously shaped and confirmed attitudes and value hierarchy, personality features and many others. In a certain setup of these factors, media help in violence justification by showing it as an effective method of achieving the goals such as power, financial means or information. Very often they also build ground for violence by presenting

${ }^{67}$ R. Langley, R.C. Levy, Wife Beating: The Silent Crisis, New York 1977, p. 73; M.D. Pagelow, L.W. Pagelow, op. cit., p. 127.

68 M.D. Pagelow, L.W. Pagelow, op. cit, p. 127.

${ }^{69}$ Ibidem, pp. 135-138.

${ }^{70}$ M.D. Pagelow, L.W. Pagelow, op. cit., pp. 128-135; S.K. Steinmetz, The Cycle..., op. cit., p. 37; K.E. Dill, J.C. Dill, Video Game Violence: A Review of the Empirical Literature, "Aggression and Violent Behavior" 1998, vol. 3, no. 4, pp. 407-428; M. Griffiths, Violent Video Games and Aggression: A Review of the Literature, "Aggression and Violent Behavior" 1999, vol. 4, no. 2, pp. 203-212; E. Conduit, The Angry Man's Television, "The Criminologist" 1993/94, vol. 17, no. 2, pp. 70-75; M. Chatterton, op. cit., pp. 26-49; L.A. Bealieu, Media, Violence and the Family: A Canadian View, [in:] J.M. Eekelaar, S.N. Katz (eds.), Family Violence - an International and Interdisciplinary Study, Toronto 1978, pp. 58-68; E. Aronson, op. cit., pp. 320-332; K. KmiecikBaran, op. cit., pp. 47-52.

${ }^{71}$ L.A. Bealieu, op. cit., pp. 58-59; N. Shainess, Psychological Aspects of Wife-Battering, [in:] M. Roy (ed.), op. cit., p. 113; M.P. Stasiukiewicz, Agresja i przemoc jako element kultury symbolicznej. Mechanizmy kreowania przemocy poprzez oddziaływanie mediów, [in:] M. BinczyckaAnholcer (ed.), op. cit., pp. 231-240; M. McKenzie, Domestic Violence in America, Brunswick 1995, p. 73. 
attractive but unreachable lifestyles, which causes frustration. Sometimes they stimulate violence or aggression directly. ${ }^{72}$ They also teach criminal techniques and create common images of violent crimes, ${ }^{73}$ "typical" crime, "typical" wrongdoer and "typical" victim. ${ }^{74}$ They teach how to be a wrong-doer by presenting violence as a very effective social technique and how to be a victim by showing patterns of provocation or submission. ${ }^{75}$ One of the most crucial issues is making an influence on forming moral norms, preferable values, attitudes towards violence. This influence is subtle, indirect: through presenting models (attractive people of success) who use violence and are rewarded for it. Violence is showed as a normal, common way of solving problems and a typical method of an expression of negative emotions. Media create "the right" behaviors associated with a social role and very often they promote a disturbed relationship between people (which is usually more interesting than the proper ones). ${ }^{76}$

In my opinion, an important psychological reason for using violence is disappearance of deep emotionality. Our lives nowadays are more and more technical, direct, interpersonal communication is replaced by electronic devices and so it is simplified; because of the decreasing of work market people have to compete with one another, using manipulation against potential rivals. Contemporary societies follow dissociative personality pattern. ${ }^{77}$ Fortunately, in the last 5-6 years the opposite trends have also appeared, although they have not been commonly shared. A society does not have a personality, but some features, specific for the dissociative personality, quite often appear among society members and they are accepted. ${ }^{78}$ They are: the lack of social fear, lack of empathy and Machiavellism. ${ }^{79}$

The lack of social fear makes a person not take an approved behavior or take an unapproved one because he/she is not afraid of negative consequences that may follow. In the contemporary society close interpersonal bonds are not common, especially among the members of small social groups (family, neighborhood). Their influence on the members' behavior, on forming social rules, decreases. Their abilities to enforce the approved behavior and to condemn individuals who disobey is vanishing. The social fear of being excluded from the society is not now

${ }^{72}$ L.A. Bealieu, op. cit, pp. 60-61; A. Peyrefitte, op. cit., pp. 95-99; M.R. Chatterton, op. cit., p. $33 \mathrm{ff}$.

${ }^{73}$ L.A. Bealieu, op. cit., p. 61; M.R. Chatterton, op. cit., p. 33.

${ }^{74}$ M.R. Chattreton, op. cit., pp. 35-36.

${ }^{75}$ L.A. Bealieu, op. cit., p. 60, 61, 63.

${ }^{76}$ W. Poznaniak, Teorie uczenia się społecznego jako model normalnego i zaburzonego funkcjonowania jednostki oraz grupy, [in:] H. Sęk (red.), Społeczna psychologia kliniczna, Warszawa 1991, pp. 90-94; L.A. Bealieu, op. cit., p. 60.

77 M. Budyn-Kulik, Psychologiczne i wiktymologiczne aspekty prostytucji, [in:] M. Mozgawa (red.), Prostytucja, Warszawa 2014, pp. 268-269.

78 A. Jakubik, Zaburzenia osobowości, Warszawa 1999, pp. 62-73.

79 K. Pospiszyl, Psychopatia, Warszawa 2000, pp. 13-35; A. Jakubik, op. cit., pp. 52-53. 
a motivation for fulfilling the social expectations and following rules while an individual does not feel a part of it and when a society members do not have a real influence on his/her life. In a small group with close bonds, where people know one another well, rejecting the society rules effects with being left alone. It has also its disadvantages - if one of the rules is approval for using violence, victims cannot count on any help. In the contemporary (Western world) society, people do not know their neighbors in the real world. They do have an influence on creating their own society in the virtual world - in social media. People know one another only in this artificial environment, not in reality. That gives them the opportunity to create their own image the way they want to - even if it is completely false. It makes it easier to behave in an appropriate way without a cognitive dissonance (the collision between ideal "self"-idealistic way a person thinks about himself/ herself and real "self" - what a person is really like). ${ }^{80}$

Lack of empathy consists in inability to understand other people's feelings (emotions). One can observe the separation process between the emotional and cognitive sphere (especially among youngsters). As far as the cognitive sphere is concerned the development is accelerated. But the emotional development is slowing down. The emotional reactivity is also changing. Our emotional sensitivity decreases; we need stronger stimuli to react (desensitization phenomena). Violence is a strong stimulus - a spectacular one (with realistic effects) - it gives an individual the opportunity to participate in violence without any negative consequences such as experiencing pain, shame or remorse.

Machiavellism consists in treating people as if they were things, in manipulating them for one's own purposes, in using them. Individuals are used to treating one another as if they were objects; there is no reason then not to perceive himself/ herself (and also others) as goods for sale. The ideology that the end justifies the means is quite popular nowadays. If one of the means is violence then it should be used, as long as it works.

Since violence is well approved of and commonly used it is very difficult to counteract it. The official attitude towards violence is that "it is wrong", but many people who condemn violent behavior in general, on abstract level, are eager to use violence when it suits their needs. That is why it is so difficult to change the attitude towards violence. It is important to change not the surface attitude, but the real, deep one. Attitude towards violence is a classical social dilemma. If one stops using violence it is a benefit both for himself/herself and for the whole society. But if only an individual or a small group (not everyone) resigns from using violence, then they become helpless in front of those who do not resign.

In public discussions the thesis is often presented that the law does not protect victims from violence. This thesis is, at the same time, true and false.

${ }^{80}$ A. Jakubik, op. cit., pp. 164-168. 
It is false because legal acts: the international acts, the Polish Constitution, the Parliament acts and the implementing acts enforce many measures aiming at the elimination of violence from the society. But on the other hand, it is true because if an individual is not convinced that certain attitude (e.g. non-violent behavior) is appropriate, it is impossible to force the desired behavior on him/her (especially with the policy of punishment that we are having at present). One can be punished for bad behavior. Unfortunately, and it is not only Polish experience, without changing this deep attitude punishment is not enough. The problem is that if an individual uses violence for communication, then he/she does not respect any other way of communication. If the state (society) treats him/her with mercy he/she perceives it as a sign of weakness not an act of grace. If the state (society) uses violent measures itself, then it deprives itself of the moral right to condemn an aggressive individual. ${ }^{81}$

In the last dozen years or so, the Polish (but also European) criminal policy is resocialization instead of punishment. The so-called restorative justice is becoming more and more popular. That, in association with some changes in the Criminal Code or Criminal Procedure Code (e.g. Art. 37a, 37b, 58 § 1, 59 C.C., mediation), may lead to the conviction a wrong-doer may build - the feeling of being unpunishable. Although punishment itself cannot change a deep attitude toward anything, being consistent in punishing for violent crimes may make committing them unprofitable. Consequence in punishing for violent crimes can be perceived as a conditioning.

\section{BIBLIOGRAPHY}

Andersen, S.M., Boulette, T.B., Schwartz, A.H., Psychological Maltreatment of Spouses, [in:] R.T. Ammerman, M. Hersen (eds.), Case Studies in Family Violence, New York-London 1991. Aronson, E., Człowiek istota społeczna, Warszawa 1995.

Bealieu, L.A., Media, Violence and the Family: A Canadian View, [in:] J.M. Eekelaar, S.N. Katz (eds.), Family Violence - an International and Interdisciplinary Study, Toronto 1978.

Błachut, J. Gaberle, A. Krajewski, K., Kryminologia, Gdańsk 1999.

Browne, K., Herbert, M., Zapobieganie przemocy w rodzinie, Warszawa 1999.

Budyn-Kulik, M., Psychologiczne $i$ wiktymologiczne aspekty prostytucji, [in:] M. Mozgawa (red.), Prostytucja, Warszawa 2014.

Budyn-Kulik, M., Oddziaływanie na sprawców przemocy w rodzinie przez sądy poprzez nakładanie obowiazku uczestnictwa w programach korekcyjno-edukacyjnych, Warszawa 2012, raport IWS, https://www.iws.org.pl/ badania/raporty\#prawo\%20karne\%202012 [access: 14.03.2017].

Budyn-Kulik, M., Zabójstwo tyrana domowego. Studium prawnokarne $i$ wiktymologiczne, Lublin 2005.

${ }^{81}$ See a research on participation of domestic violence perpetration in corrective-educational programs, M. Budyn-Kulik, Oddziaływanie na sprawców przemocy w rodzinie przez sądy poprzez nakładanie obowiazku uczestnictwa w programach korekcyjno-edukacyjnych, Warszawa 2012, raport IWS, https://www.iws.org.pl/ badania/raporty\#prawo\%20karne\%202012 [access: 14.03.2017]. 
Budyn-Kulik, M., Kulik, M., Glosa do uchwały Sadu Najwyższego z dnia 30 czerwca 2008 r., I KZP 10/08, System informacji prawnej LEX/el. 2009, nr 93962.

Budyn-Kulik, M., Kulik, M., Glosa do uchwały Sądu Najwyższego z dnia 21 marca 2007, I KZP 39/06, PS 2009, nr 5.

Chatterton, M.R., The Social Context of Violence, [in:] M. Borland (ed.), Violence in the Family, Manchester 1976.

Conduit, E., The Angry Man's Television, "The Criminologist" 1993/94, vol. 17, no. 2.

Coser, L.A., Some Social Functions of Violence, [in:] M.E. Wolfgang (ed.), Patterns of Violence. The Annals of the American Academy of Political and Social Science, Philadelphia 1966, nr 364.

Daszkiewicz, K., Groźba w polskim prawie karnym, Warszawa 1958.

Dill, K.E ,Dill, J.C., Video Game and Violence: A Review of the Empirical Literature, "Aggression and Violent Behavior" 1998, vol. 3, no. 4.

Domachowski, W., Czy przemoc $i$ agresja sq ze sobq powiazane $i$ czy wplywaja na zdrowie psychiczne?, [in:] M. Binczycka-Anholcer (red.), Agresja i przemoc a zdrowie psychiczne, Warszawa-Poznań 2001.

Drząszcz, A., Oddziaływanie hormonów na agresywna postawe ludzi, „Studia Kryminologiczne, Kryminalistyczne i Penitencjarne" 1976, t. 5.

Dutton, D.G., Limitations of Social Learning Models in Explaining Intimate Aggression, [in:] X.B. Arriaga, S. Oskamp (eds.), Violence in Intimate Relationships, Thousand Oaks-London-New Delhi 1999.

Farrington, K.M., Stress and Family Violence, [in:] M.A. Straus, T. Hotaling (eds.), The Social Causes of Husband-Wife Violence, Minneapolis 1980.

Fonberg, E., Fizjologiczna regulacja agresji, „Psychologia Wychowawcza” 1973, nr 3.

Frączek, A., Agresja - psychologiczny punkt widzenia, [in:] A. Frączek (red.), Z zagadnień psychologii agresji, Warszawa 1980.

Frączek, A., O Ericha Fromma koncepcji ludzkiej destruktywności, [in:] A. Frączek (red.), Studia nad uwarunkowaniami i regulacja agresji interpersonalnej, Wrocław 1986.

Geller, S., Funkcje mechanizmów poznawczych w regulacji agresji, [in:] A. Frączek (red.), Z zagadnień psychologii agresji, Warszawa 1980.

Gierowski, J.K., Niektóre biopsychiczne determinanty agresywnego zachowania przestępczego, „Studia Kryminologiczne, Kryminalistyczne i Penitencjarne” 1979, t. 9.

Gierowski, J.K. Wpływ typu i poziomu agresywności sprawcy na zachowania homicidalne, „Psychiatria Polska” 1995, t. XXIX, nr 1.

Godzeń, L., Moralna aprobata zachowań agresywnych a doświadczenia jednostki $w$ zakresie agresji, [in:] B. Urban (red.), Społeczne konteksty zaburzeń w zachowaniu, Zeszyty Naukowe Uniwersytetu Jagiellońskiego, Prace Pedagogiczne 2001, z. 28.

Golden, C.J. Jackson, M.L. Peterson-Rohne, A. Gontkovsky, S.T., Neuropsychological Correlates of Violence and Aggression: A Review of the Clinical Literature, "Aggression and Violent Behavior" 1996, vol. 1, no. 1.

Greene, A.F. Lynch, T.F. Decker, B.A., Psychobiological Theoretical Characterization of Interpersonal Violence Offenders, "Aggression and Violent Behavior" 1997, vol. 2, no. 3.

Griffiths, M., Violent Video Games and Aggression: A Review of the Literature, "Aggression and Violent Behavior" 1999, vol. 4, no. 2.

Hanausek, T., Przemoc jako forma działania przestępnego, Kraków 1966.

Haque, G. Malos, E., Domestic Violence Action for Change, Cheltenham 1994.

Harris, M.B., Aggression, Gender and Ethnicity, "Aggression and Violent Behavior" 1996, vol. 1, no. 2 .

Heitzman, J., Stres w etiologii przestępstw agresywnych, Kraków 2002.

Jakubik, A., Zaburzenia osobowości, Warszawa 1999.

Karlsson, I., Ein Gebrochenes Tabu. Frauenhäuser in Österreich, Wien 1988. 
Karolczak-Biernacka, B., Problem agresji w sporcie, [in:] B. Hołyst (red.), Przemoc w życiu codziennym, Warszawa 1997.

Kmiecik-Baran, K., Młodzież i prawo. Mechanizmy socjologiczno-psychologiczne, Warszawa 2000.

Krajewski, K., O pojęciu przemocy w kryminologii, „Studia Kryminologiczne, Kryminalistyczne i Penitencjarne" 1988, t. 19.

Krukowski, A., Agresja w aspekcie prawa karnego i kryminologii, „Psychologia Wychowawcza” 1973, nr 3.

Kubala, W., Znamię „przemocy” w ujęciu art. 123 k.k., „Problemy Praworządności” 1987, nr 8-9.

Langley, R., Levy, R.C., Wife Beating: The Silent Crisis, New York 1977.

Martin, M., Battered Wives (revised, updated), San Francisco 1981.

McClintock, F.H., Criminological Aspects of Family Violence, [in:] J.P. Martin (ed.), Violence and the Family, New York-Brisbane-Toronto 1978.

McKenzie, M., Domestic Violence in America, Brunswick 1995.

Mitchell, A.R.K., Violence in the Family, Hove-East Sussex 1978.

Moir, A., Jessel, D., Zbrodnia rodzi się w mózgu. Zagadka biologicznych uwarunkowań przestępczości, Warszawa 1998.

Nelken, J., Endogenne czynniki przestępczości w świetle polskiej myśli kryminologicznej, „Państwo i Prawo" 1984, z. 9.

Neuebauer, U., Steinbrecher, U., Drescher-Aldendorff S., (Hrsg.), Gewalt gegen Frauen: Ursachen und Interventionsmöglichkeit. Gesellschaft für Familienforschung e.u. (GEFAM). Schriftenseite des Bundesminister für Jugend, Familie, Frauen und Gesundheit, Stuttgart-BerlinKöln-Mainz 1987, vol. 21.

Pagelow, MD., Pagelow, L.W., Family Violence, New York 1984.

Pełka-Sługocka, M.D., Sługocki, L., Przestępstwa przy użyciu przemocy popetniane przez kobiety w Polsce, „Studia Kryminologiczne, Kryminalistyczne i Penitencjarne” 1983, t. 13.

Peyrefitte, A., Społeczeństwo wobec przemocy. Raport Komitetu Badań nad przemoca, zbrodnia $i$ wystepkiem, Warszawa 1982.

Pospiszyl, I., Przemoc w rodzinie, Warszawa 1998.

Pospiszyl, K., Psychopatia, Warszawa 2000.

Pospiszyl, K., Narcystyczne źródła agresji interpersonalnej, [in:] B. Hołyst (red.), Przemoc w życiu codziennym, Warszawa 1997.

Poznaniak, W., Teorie uczenia się społecznego jako model normalnego i zaburzonego funkcjonowania jednostki oraz grupy, [in:] H. Sęk (red.), Społeczna psychologia kliniczna, Warszawa 1991.

Renvoize, J., Web Violence. A Study of Family Violence, London 1978.

Reykowski, J., Funkcjonowanie osobowości w warunkach stresu psychologicznego, Warszawa 1966.

Reykowski, J., Osobowościowe i sytuacyjne przesłanki agresji, „Psychologia Wychowawcza” 1973, $\mathrm{nr} 3$.

Rodniański, J., Klasyfikacja, źródła i ocena przemocy w stosunkach międzyludzkich, [in:] B. Hołyst (red.), Przemoc w życiu codziennym, Warszawa 1997.

Sankała, A., Przemoc jako przejaw patologizacji więzi międzyludzkich, [in:] B. Hołyst (red.), Przemoc w życiu codziennym, Warszawa 1997.

Schneider, H.J., Przemoc w instytucjach, [in:] B. Hołyst (red.), Przemoc w życiu codziennym, Warszawa 1997.

Senthilathiban, K., Modhava Soma Sundaram, R., Karunahidhi, S., Reactions to Wife-Beating: an Opinion Survey Among Students, "Indian Journal of Criminology” 1991, vol. 19, no. 1.

Shainess, N., Psychological Aspects of Wife-Battering, [in:] M. Roy (ed.), Battered Woman. A Psychological Study of Domestic Violence, New York 1977.

Sigler, R.T., Domestic Violence in Context: An Assessment of Community Attitude, Lexington 1989.

Skorny, Z., Formy i źródła agresji u dzieci i młodzieży, „Psychologia Wychowawcza” 1973, nr 3. 
Stasiukiewicz, M.P., Agresja i przemoc jako element kultury symbolicznej. Mechanizmy kreowania przemocy poprzez oddziaływanie mediów, [in:] M. Binczycka-Anholcer (red.), Agresja i przemoc a zdrowie psychiczne, Warszawa-Poznań 2001.

Steinmetz, S.K., The Cycle of Violence, New York 1977.

Steinmetz, S.K., Wife-beating, Husband-beating - A Comparison of the Use of Physical Violence Between Spouses to Resolve Marital Fights, [in:] M. Roy (ed.), Battered Woman: A Psychosociological Study of Domestic Violence, New York 1977.

Stets, J.E., Domestic Violence and Control, New York 1988.

Stratton, P., Understanding and Treating Child Abuse in the Family Context: An Overview, [in:] K. Browne, C. Davies, P. Straton (eds.), Early Prediction and Prevention of Child Abuse, Chichester 1988.

Straus, M.A., Conceptualization and Measurement of Battering: Implications for Public Policy, [in:] M. Steinmann (ed.), Woman Battering: Policy Responses, Lincoln 1991.

Szabo, D., Agresja, przemoc i systemy socjokulturowe: Typologia, „Studia Kryminologiczne, Kryminalistyczne i Penitencjarne" 1975, t. 2.

Szyszko-Bohusz, A., Agresja, przemoc i zdrowie psychiczne w relacji do Hipotezy Nieśmiertelności Genetycznej, [in:] M. Binczycka-Anholcer (red.), Agresja i przemoc a zdrowie psychiczne, Warszawa-Poznań 2001.

Szyszko-Bohusz, A., Przemoc jako antynomia miłości, [in:] B. Hołyst (red.), Przemoc w życiu codziennym, Warszawa 1997.

Violence Against Women in the Family - United nations Office at Vienna, Centre for Social Development and Humanitarian Affairs, New York 1989.

Walker, L.E., Psychological Causes of Family Violence, [in:] M. Lystad (ed.), Violence in the Home. Interdisciplinary Perspectives, New York 1986.

Walker, L.E., The Battered Woman Syndrome, [in:] R.J. Gelles, D.R. Loseke (eds.), Current Controversies on Family Violence, Newbury Park-London-New Delhi 1993.

Warylewski, J., Molestowanie seksualne w miejscu pracy, „Państwo i Prawo” 1999, z. 3.

Wolfgang, M.E., A Preface to Violence, [in:] M.E. Wolfgang (ed.), Patterns of Violence, The Annals of the American Academy of Political and Social Science, Philadelphia 1966, no. 364.

Wolska, A., Mechanizmy agresji zabójców, „Czasopismo Psychologiczne” 1997, t. 3, nr 3.

Zimbardo, R.G. Ruch, F.L., Psychologia $i$ życie, Warszawa 1994.

Zoll, A., Glosa do uchwaty SN z dn. 10 grudnia 1998, I KZP 22/98, OSP 1999, z. 5, poz. 93.

\section{SUMMARY}

Violence is a social fact. According to general opinion, it is a negative phenomenon, but one may also perceive it as a neutral phenomenon. The term "violence" is very broad. It is not easy to define it. Its range is changing, what is more, the same behaviors in different social contexts can be interpreted as violence or not. Violence is not the same as aggression, although they are connected. The nature of violence and aggression is a controversial problem: are they intuitive or learned? Probably one's tendency to use violence and aggression is caused by many factors. There are lot of theories that try to explain the nature of violence. Using violence is determined by psychological, biological and socio-cultural factors. Punishment itself cannot change a deep attitude toward anything, but being consistent in punishing for violent crimes may make committing them unprofitable.

Keywords: violence; criminology; theories: criminal law aggression 


\section{STRESZCZENIE}

Przemoc jest faktem społecznym. W powszechnej opinii ma zawsze charakter negatywny, ale można ja także traktować jako zjawisko neutralne. Sam termin jest szeroki. Nie jest go łatwo zdefiniować. Jego zakres się zmienia, co więcej, takie samo zachowanie w różnych kontekstach społecznych może być interpretowane jako przemoc lub nie. Przemoc nie jest tożsama $z$ agresją, chociaż są one ze sobą powiązane. Problematyczna jest kwestia, czy przemoc i agresja są wrodzone czy wyuczone. Prawdopodobnie tendencja do zachowań przemocowych lub agresywnych jest efektem oddziaływania różnych czynników. Istnieje wiele teorii próbujących wyjaśnić naturę przemocy - przy pomocy czynników psychologicznych, biologicznych oraz socjokulturowych. Chociaż kara sama w sobie nie jest w stanie zmienić postawy człowieka, to konsekwentne karanie sprawców przestępstw z użyciem przemocy może uczynić ich popełnianie nieopłacalnym.

Słowa kluczowe: przemoc; kryminologia; teorie; prawo karne; agresja 